\title{
Canine carcinomas in benign mixed tumours: versican expression and association with invasion
}

\author{
Karine A Damasceno ${ }^{1}$, Angélica C Bertagnolli², Alessandra Estrela-Lima³ ${ }^{3}$ Lorena GR Ribeiro ${ }^{3}$, Bruna S Rabelo ${ }^{1}$, \\ Cecília B Campos ${ }^{1}$, André LB Barros ${ }^{4}$, Geovanni D Cassali ${ }^{1 *}$ \\ From São Paulo Advanced School of Comparative Oncology \\ Águas de São Pedro, Brazil. 30 September - 6 October 2012
}

\section{Background}

Components of the extracellular matrix have been studied in the attempt to elucidate the mechanisms involved with biological behavior of tumours. The presence of the proteoglycan versican has been strongly associated to cancer development and progression, however its relationship with invasion and tumoral progression has been little studied in veterinary medicine. Carcinomas in benign mixed tumours (CBMT) are one of the most common malignant tumour in female dogs and can serve as a model for studies on tumour progression. The aim of this paper was to evaluate the expression of versican in in situ and invasive carcinomatous areas of CBMT.

\section{Materials and methods}

Immunohistochemical staining for versican and confirmation of invasion areas with staining for p63 and smooth muscle $\alpha$-actin ( $\alpha$-SMA) were performed on 49 cases of CBMT.

\section{Results}

Invasion was considered when suspicious HaematoxylinEosin stained areas revealed a total loss of immunoreactivity for $\alpha$-SMA and p63. Versican immunoreactivity was less intense adjacent to in situ carcinomatous regions when compared to invasive regions in which staining was found as more extensive areas with strong expression.

\section{Conclusions}

Obtained data reveal that, in carcinomas in benign mixed tumors, versican expression differs significantly within

\footnotetext{
* Correspondence: cassalig@icb.ufmg.br

'Department of General Pathology, Biological Sciences Institute, Universidade Federal de Minas Gerais, Belo Horizonte, MG, Brazil Full list of author information is available at the end of the article
}

invasive and in situ areas, suggesting the role of this molecule in tumor progression.

\section{Financial support \\ FAPEMIG, CNPq and CAPES}

\section{Author details}

'Department of General Pathology, Biological Sciences Institute, Universidade Federal de Minas Gerais, Belo Horizonte, MG, Brazil. ${ }^{2}$ Fepagro Animal Health Desidério Finamor Institute of Veterinary Research (IPVDF), Eldorado do Sul, RS, Brazil. ${ }^{3}$ Department of Pathology and Clinics, School of Veterinary Medicine and Zootechny, Universidade Federal da Bahia, Salvador, BA, Brazil. ${ }^{4}$ Department of Clinical and Toxicological Analyses, School of Pharmacy, Universidade Federal de Minas Gerais, Belo Horizonte, MG, Brazil.

Published: 4 April 2013

doi:10.1186/1753-6561-7-S2-P39

Cite this article as: Damasceno et al: Canine carcinomas in benign mixed tumours: versican expression and association with invasion. $B M C$ Proceedings 2013 7(Suppl 2):P39.
Submit your next manuscript to BioMed Central and take full advantage of:

- Convenient online submission

- Thorough peer review

- No space constraints or color figure charges

- Immediate publication on acceptance

- Inclusion in PubMed, CAS, Scopus and Google Scholar

- Research which is freely available for redistribution
C Biomed Central
C Biomed Central 